\title{
Effects of Restraint Stress on Components of Adenylyl Cyclase Signal Transduction in the Rat Hippocampus
}

\author{
David Wolfgang, B.S., Irene Chen, B.S., and Gary S. Wand, M.D.
}

Chronic stress can injure hippocampal neurons as well as alter hippocampal function. The adenylyl cyclase (AC) signal transduction system is an important modulator of neurotransmission in this brain region. This study was conducted to begin to understand the effects of chronic stress on the hippocampal AC system. To assess dependence of type I and type II AC mRNA expression on adrenal integrity, total RNA was prepared from the hippocampus of nonstressed rats 7 days following either sham surgery or adrenalectomy (ADX). Adrenalectomy resulted in a $60 \%$ diminution in steady-state expression of type II AC mRNA ( $p<.005)$ and a nonsignificant fall in type I AC mRNA expression. Both sham and adrenalectomized rats were then exposed to 1-hour sessions of restraint, twice per day $(0800$ to 0900 and 1500 to 1600 hours) for 4 days. Following the stress paradigm, RNA was prepared from the hippocampus and type I and type II AC mRNA levels determined by Northern blot. Densitometic analysis showed that in comparison to unstressed sham rats, stressed sham rats had a significant twofold increase in steady-state levels of type I and type II mRNA. Stressed adrenalectomized rats also had increased expression in type II AC mRNA but no significant stress-induced change in expression of type I AC $m R N A$. To assess dependence of hippocampal membrane G-Proteins on adrenal integrity, hippocampal membranes from nonstressed rats 7 days following either sham surgery or adrenalectomy $(A D X)$ were analyzed by immunoblot. Adrenalectomy resulted in a $25 \%$ diminution in membrane Gs $\alpha$ content $(p<.05)$, but $A D X$ did not significantly change membrane Gi(1) $\alpha$, $G i(2) \alpha, G \beta_{36}$ or Go $\alpha$ content. In Sham animals, the stress paradigm resulted in increased levels of membrane Gs $\alpha$, Goo and G $\beta$. Adrenalectomy blocked the effects of stress on these G-protein changes. Restraint stress did not modulate the levels of Gi(1) $\alpha$ or Gi(2) $\alpha$. Restraint stress induced a small but significant increase in both $A C$ activity and CAMP levels in hippocampus of both sham and adrenalectomized rats. In summary, components of the hippocampal AC signal transduction system and Goo are modulated by factors released during stress.

[Neuropsychopharmacology 11:187-193, 1994]
KEY WORDS: Chronic stress; Hippocampus; Hippocampal AC signal transduction system

Stress constitutes any perturbation of homeostasis. The release of adrenal glucocorticoids and catecholamines under conditions that threaten homeostasis represents

From the Departments of Medicine and Psychiatry, The Johns Hopkins University School of Medicine, Baltimore, Maryland.

Address correspondence to: Gary S. Wand, M.D., Associate Professor of Medicine and Psychiatry, Division of Endocrinology, Ross Bldg. Room 1032, The Johns Hopkins University School of Medicine, 720 Rutland Avenue, Baltimore, MD 21205.

Received April 12, 1994; revised May 26, 1994; accepted June 6, 1994. one of the central adaptive mechanisms among mammals. Adrenal-derived stress hormones increase free fatty acid levels, elevate blood glucose, and assist the organism by increasing the availability of energy substrates (Munck et al. 1984). Furthermore, glucocorticoids play a key role in regulating cytokine production and immune function (Sternberg et al. 1989). There is great individual variability in the magnitude and duration of the stress response (Sternberg et al. 1989). There is growing appreciation that excessive production of stress hormones during chronic stress can have deleterious consequences on biological fitness (Meaney et al. 1988; Sternberg et al. 1989; Sapolsky and Plotsky, 1990). 
Mechanisms underlying stress-induced CNS injury have not been well characterized. However, recent evidence shows that chronic stress can modulate components of adenylyl cyclase (AC) signal transduction in the pituitary and influence important cellular function (Morrill et al. 1993).

The AC complex is composed of three separate proteins embedded in the plasma membrane: receptors, GTP-binding proteins (G-proteins), and catalytic protein (AC) (Gilman 1990). G proteins are heterotrimers, consisting of $\alpha, \beta$, and $\gamma$ subunits. The $\alpha$ subunits, which contain the guanine nucleotide binding site and GTPase activity, vary among G-proteins and confer on them their specificity of interaction with receptors and effectors. Two $\mathrm{G}$ proteins, $\mathrm{Gs}$ and $\mathrm{Gi}$, mediate hormone and/or neurotransmitter stimulation or inhibition, respectively, of adenylate cyclase activity. There are four forms of $G s \alpha$, two large $(52 \mathrm{kD})$ and two small $(45 \mathrm{kD})$, derived from alternative splicing of a single Gs $\alpha$ mRNA (Van Sande et al. 1990; Chabre et al. 1992;). Three different $\mathrm{Gi}$ proteins (arbitrarily designated $\mathrm{Gi}_{1}, \mathrm{Gi}_{2}$, and $\mathrm{Gi}_{3}$ ) have been identified and found to be independent gene products (Roff et al. 1985; Mumby et al. 1986). Inhibition of $A C$ in platelets by $\alpha_{2}$-adrenergic agonists can be blocked by pretreating platelet membranes with an antibody to $\alpha_{2}$, thus implicating $\mathrm{Gi}_{2}$ in the inhibition of adenylate cyclase (Taussig et al. 1993). $\mathrm{Gi}_{3}$ may be a modulatory of potassium channel activity (Codina et al. 1986).

The $\beta \gamma$ dimer is tightly associated with a GDPbound $\alpha$ chain and facilitates interaction of the $G$ protein with a receptor molecule. In addition to their role regulating $\alpha$ chain function, the $\beta \gamma$ subunits themselves appear capable of transmitting intracellular messages in some cells and may anchor the $\alpha \beta \gamma$ complex to the cell membrane (Tang and Gilman 1991).

Finally, there are multiple forms of $\mathrm{AC}$, each a unique gene product (Mumby et al. 1986; Feinstein et al. 1991; Gao and Gilman 1991; Tang et al. 1991; Tang and Gilman 1992). The brain contains a calmodulin sensitive (Type I) and a calmodulin-insensitive (Type II) $\mathrm{AC}$ as well as an AC found in olfactory tissue (Type III) and in striatum (Type IV).

In this study, we investigated the effects of restraint stress on the various components of the AC system in the hippocampus of the rat.

\section{METHODS}

\section{Restraint Stress}

Male Fisher/344 rats (Harlan Sprague-Dawley; Indianapolis, IN) weighing 200 to $250 \mathrm{~g}$ were housed five per cage in a quiet temperature- $\left(22^{\circ} \mathrm{C}\right)$ and lightcontrolled environment, ( 12 hours of light, 12 hours of darkness). Animals were maintained in accordance with the NIH Guide for the Care and Use of Laboratory Animals. Seven days prior to stress experiments, rats underwent sham surgery or adrenalectomy (Harlan) via $10 \mathrm{~mm}$ bilateral flank incisions following intramuscular injection of Ketamine $(4.1 \mathrm{mg})$ with Xylazine $(0.85$ $\mathrm{mg} / 100 \mathrm{gm}$ body weight); adrenalectomized rats were maintained on $0.9 \%$ saline. There was mortality in either group. Rats were randomized to control or stress groups. Rats were exposed to 1-hour sessions of restraint, twice per day (0800 to 0900 hours and 1500 to 1600 hours) for 4 days (Hauger et al. 1990). Control rats were left in their cages. At the completion of stress, rats were quickly guillotined, indicated tissues removed, and blood immediately collected. Serum was prepared and stored at $-70^{\circ} \mathrm{C}$. Plasma corticosterone was measured by RIA (ICN, Bakersfield, CA).

\section{Membrane Preparation}

Membranes were prepared as described (Wand et al. 1993). Tissue homogenates were spun at $500 \times \mathrm{g}$ for 5 minutes at $4^{\circ} \mathrm{C}$ to remove the nuclear pellet. The supernatant was then spun at $20,000 \times g$ for 20 minutes at $4^{\circ} \mathrm{C}$. The pellet was washed twice in wash buffer (lysis buffer without sucrose). The final membrane pellet was diluted with wash buffer and stored at $-70^{\circ} \mathrm{C}$. Protein concentration was determined by bicinchonic acid reaction with BSA as standard.

\section{Adenylyl Cyclase Activity}

Adenylyl cyclase activity of membrane preparations was determined in triplicate by a modification of the method of Salomon et al. (1974). Aliquots (5 to $20 \mu \mathrm{g}$ ) of membrane protein were assayed in $100 \mu \mathrm{l}$ final volume containing $0.1 \mathrm{mmol} / \mathrm{Lm}\left(\alpha^{-32} \mathrm{P}\right)$-ATP $(1 \mu \mathrm{Ci})$, $2.8 \mathrm{U}$ creatine phosphokinase, $5 \mathrm{mmol} / \mathrm{L}$ creatine phosphate, $1.5 \mathrm{mmol} / \mathrm{L} \mathrm{MgCl} 2,19.2 \mathrm{mg} \% \mathrm{BSA}, 50 \mathrm{mmol} / \mathrm{L}$ Na-Hepes ( $\mathrm{pH} 7.6), 0.3 \mathrm{mmol} / \mathrm{L} \mathrm{KCL}, 0.2 \mathrm{mmol} / \mathrm{L}$ cAMP, and $1 \mathrm{mmol} / \mathrm{L}$ dithiothreitol. Samples were incubated at $30^{\circ} \mathrm{C}$ for 20 minutes with no further additions (basal) or in the presence of $10 \mathrm{mmol} / \mathrm{L} \mathrm{NaF}$ or $10 \mu \mathrm{mol} / \mathrm{L} \mathrm{GTP}-\gamma-\mathrm{S}$. The reaction was terminated by the addition of $100 \mu 150 \mathrm{mmol} / \mathrm{L}$ Hepes (pH 7.5), $2 \mathrm{mmol} / \mathrm{L}$ ATP, $0.5 \mathrm{mmol} / \mathrm{L} 3 \mathrm{H}-\mathrm{cAMP}(15 \mathrm{nCi}), 2 \% \mathrm{SDS}$, and heating to $100^{\circ} \mathrm{C}$ for 3 minutes. Cyclic AMP was isolated by chromatography. Recovery averaged $87 \%$. Cyclic AMP levels were measured from hippocampal acid extracts as previously described (Wand et al. 1993).

\section{Immunoblot Analysis}

For immunoblot analysis (Wand et al. 1993), membrane proteins $(50 \mu \mathrm{g})$ were fractionated by electrophoresis through $10 \%$ SDS-polyacrylamide gels ( $10 \%$ acryl- 


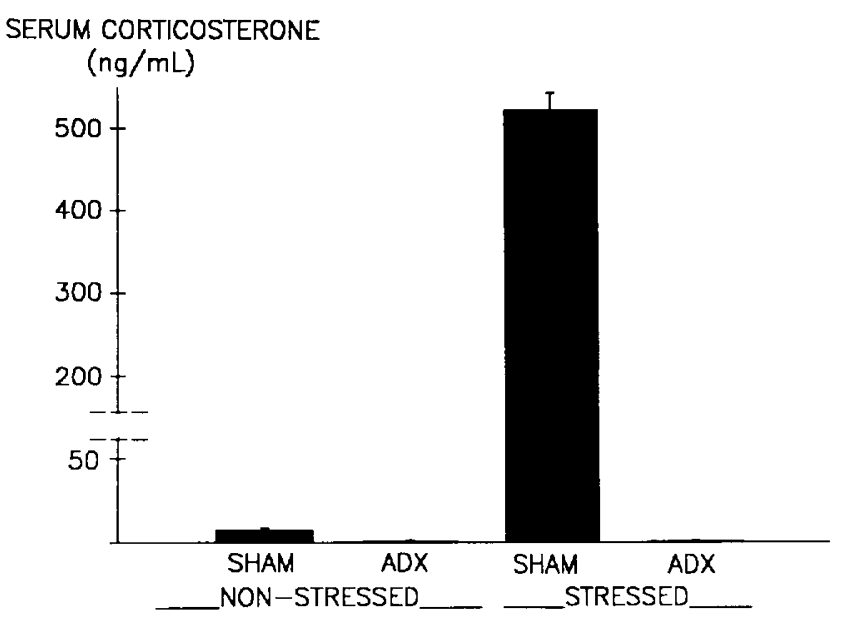

Figure 1. Effects of $A D X$ and restraint stress on serum corticosterone levels. Serum corticosterone levels were determined in nonstressed/sham $(n=8)$, nonstressed/ADX $(n=$ $7)$, stressed/sham $(n=8)$, and stressed/ADX $(n=8)$ groups of rats.

amide, $0.13 \%$ phenylpiperazine). Proteins were electrophoretically transferred to polyvinylidine difluoride filters using a transfer bath containing $10 \%$ methanol, $0.01 \mathrm{~mol} / \mathrm{L} 3$-(cyclohexlamino)-1-Propanesulfonic acid, pH 11.0). After transfer, membranes (filters) were stained with Coomassie blue to ascertain transfer efficacy. Filters were incubated for 2 hours at room temperature in $50 \mathrm{mmol} / \mathrm{L}$ Tris, $138 \mathrm{mmol} / \mathrm{L} \mathrm{NaCl}, 2 \mathrm{mmol} / \mathrm{L}$ $\mathrm{MgCl}_{2}$, pH $7.4 \mathrm{~T}$ (TBS) containing 3\% BSA, $0.1 \%$ Tween-20, .02\% NaN3 and washed twice for 5 to 10 minutes with TBS containing $0.2 \%$ SDS, $2 \%$ Nonidet $\mathrm{P}-40$. Filters were incubated overnight at room temperature with specific primary antibodies in TBS containing $1 \%$ BSA, $0.05 \%$ Tween-20, $0.02 \% \mathrm{NaN} 3$, and $2 \%$ Nonidet P-40. Filters were washed twice for 30 minutes in wash buffer (TBS, $0.2 \%$ SDS, $2 \%$ Nonidet P-40) and incubated for 2 hours with ${ }^{125} \mathrm{I}$-protein $\mathrm{A}(0.5 \mu \mathrm{Ci} / \mathrm{ml})$ in $1 \% \mathrm{BSA}, 0.05 \%$ Tween-20 $0.02 \% \mathrm{NaN}_{3}$, and $2 \%$ Nonidet P-40. Filters were washed twice for 30 minutes and then rinsed twice for 5 to 10 minutes in wash buffer and autoradiographed. Autoradiographic image intensities were determined by two dimensional densitometry using the Molecular Dynamics personal densitometer system. Antiserum C584 recognizes C-terminal amino acids (325 to 339) of both the 45- and 52-kD forms of Gs $\alpha$ (Wand et al. 1993). Antiserum A54 recognizes $\mathrm{Gi}(2) \alpha$, a $41-\mathrm{kD}$ protein (Wand et al. 1993). Antiserum A56 recognizes $\mathrm{Gi}(1) \alpha$ and $\mathrm{Gi}(3) \alpha$ (Wand et al. 1993).

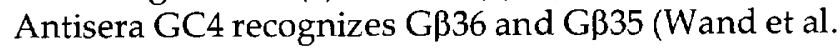
1993).

\section{RNA Analysis}

RNA was extracted by the guanidium isothiocyanate method and isolated by centrifugation through a 5.7 $\mathrm{mol} / \mathrm{L}$ cesium chloride cushion (Chirgwin et al. 1979). RNA OD 260/280 ratios ranged between 1.9 and 2.2. Total RNA was size-fractionated on $0.8 \%$ formaldehyde-agarose gels. Integrity of the RNA preparation was assessed by ethidium bromide staining and UV ( 254 $\mathrm{nm}$ ) illumination. Resolved RNA was transferred to Gene Screen Plus ${ }^{\circledR}$ nylon membranes and prehybridized and hybridized as described using random primer labeled type I and type II AC cDNA probes. Autoradiographic image intensities were determined using the Molecular Dynamics personal densitometer system. Specific mRNA signals were normalized to the hybridization signal of 18s RNA or actin mRNA.

\section{Statistics}

Differences between groups and individuals were evaluated by the Student $t$-test where appropriate.

\section{RESULTS}

To assess dependence of steady-state levels of type I and type II adenylyl cyclase (AC) mRNA on adrenal function, total RNA was prepared from the hip-

\section{NON-STRESSED}

\section{CONTROL}

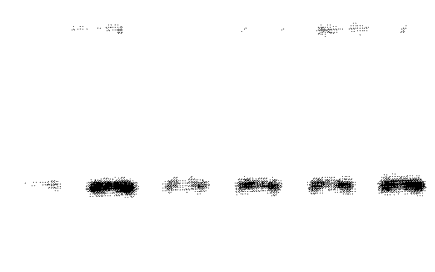

ADRENALECTOMY

Type I

Type II

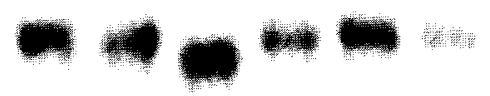

$18 s$
Figure 2. Representative Northern demonstrating adrenal dependence of steady-state levels of type I and II AC mRNA in the hippocampus. Seven days following sham surgery or adrenalectomy (ADX), steady-state expression of hippocampal type I and type II AC mRNA levels were assessed in nonstressed rats. Data are derived from individual hippocampi, and RNA was not pooled. 


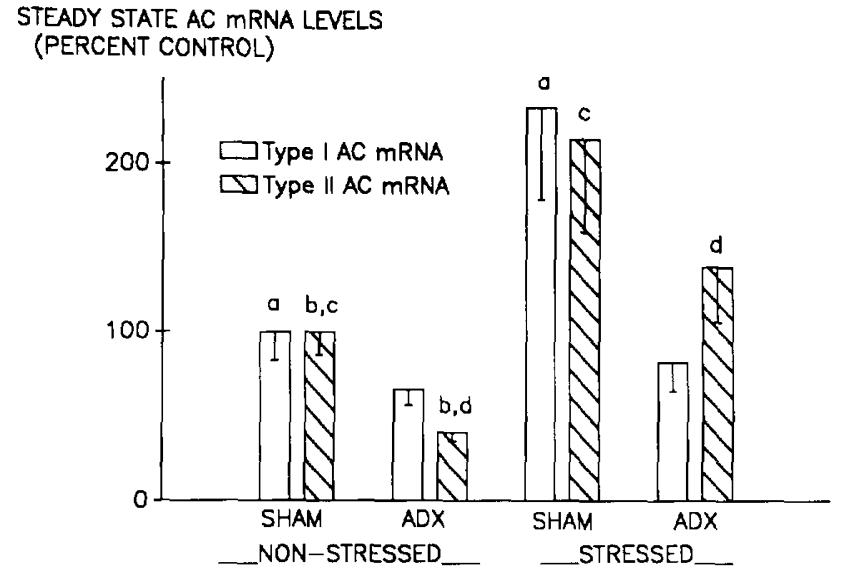

Figure 3. Densitometric analysis of the effects of restraint stress on steady state levels of type I and type II AC mRNA in the hippocampus. $a, p<.05 ; b, p<.005 ; c, p<.05 ; d, p<.02$.

pocampus of nonstressed rats 7 days following sham surgery of adrenalectomy (ADX). Adrenalectomy resulted in undetectable serum corticosterone levels (Figure 1). The Type I AC cDNA probe recognized an 11-kb mRNA, whereas the type II AC cDNA probe recognized a 4.1-kb mRNA. A representative Northern blot demonstrates that ADX resulted in a fall in steady-state expression of type I and type II AC mRNA (Figure 2). Densitometric analysis confirmed that ADX resulted in $60 \%$ fall in type II AC mRNA levels $(p<.02)$, and a nonsignificant drop in the expression of type I AC mRNA (Figure 3). Sham and adrenalectomized rats were then exposed to 1-hour sessions of restraint, twice per day (0800 to 0900 and 1500 to 1600 ) for 4 days. Nonstressed (Control) rats were left in their cages. At the completion of stress, rats were immediately guillotined, hippocampal tissue removed, trunk blood collected, and serum prepared. Following the final stress period, serum corticosterone levels were significantly elevated in the sham stressed group (Figure 1).
Following the stress paradigm, RNA was prepared from hippocampal tissue and type I and type II AC mRNA levels determined by Northern blot. Densitometric analysis of audoradiographs derived from Northern blots (Figure 3) show that stressed sham rats had a significant two-fold increase in both type I and type II AC mRNA following stress compared to nonstressed sham rats $(p<.05)$. Stressed adrenalectomized rats also showed increased expression in type II AC mRNA (Figure 3) compared to expression of type II AC mRNA in nonstressed adrenalectomized rats $(p<.02)$. Although restraint stress increased expression of type II AC mRNA in both sham and adrenalectomized rats in comparison to their nonstressed counterparts, expression of the type II mRNA was higher in the sham group $(p<.05)$. In contrast, restraint stress did not increase expression of type I AC mRNA in adrenalectomized rats.

To assess dependence of hippocampal membrane G-Proteins on adrenal integrity, hippocampal membranes from nonstressed rats 7 days following either sham surgery of adrenalectomy (ADX) were analyzed by immunoblot. Compared to Sham, ADX resulted in a $25 \%$ diminution in membrane Gs $\alpha$ content $(p<.05)$, but ADX did not significantly change membrane Gi(1) $\alpha$, $\mathrm{Gi}(2) \alpha, G \beta_{36}$, or Go $\alpha$ content (Table 1). In Sham animals, the stress paradigm resulted in increased levels of membrane Gs $\alpha$, Go $\alpha$, and G $\beta$ (Table 1). However, adrenalectomy blocked the effects of stress on these G-protein changes (Table 1). Although restraint stress did not alter the levels of $\mathrm{Gi}(3) \alpha$ and $\mathrm{Gi}(2) \alpha$ in sham animals, there was a $40 \%$ reduction in membrane $\mathrm{Gi}(1) \alpha$ content in ADX rats exposed to stress.

Hippocampal membrane AC activity as well as cAMP content was determined to assess the functional consequences of $\mathrm{ADX}$ and restraint stress on $\mathrm{AC} \mathrm{mRNAs}$ and G-protein modulation. In the nonstress setting, $\mathrm{ADX}$ resulted in a $25 \%$ reduction in hippocampal membrane $\mathrm{AC}$ activity as well as in cAMP concentrations compared
Go $\alpha$ LEVELS

\section{CONTROL}

STRESS/SHAM
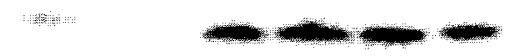

\section{STRESS/ADX}

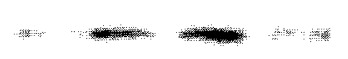

Figure 4. Representative immunoblot of Go $\alpha$ levels of the hippocampus. Nonstressed sham $(n=8)$, stressed/sham $(n=8)$, and stressed/ADX ( $n=8$ ) groups of rats were stressed as described in Methods. Following the final stress session, rats were sacrificed, hippocampal membranes prepared, and immunoblots performed as described in Methods. Data are derived from individual hippocampi, and membranes were not pooled. 
Table 1. Immunoblot Analysis

\begin{tabular}{lcccrr}
\hline Paradigm & Gs $\alpha$ & Gi(2) $\alpha$ & Gi(1) $\alpha$ & Goa & Gß36 \\
\hline Nonstressed/Sham & $100 \pm 9$ & $100 \pm 13$ & $100 \pm 5$ & $100 \pm 8$ & $100 \pm 6$ \\
Nonstressed/ADX & $77 \pm 7^{\mathfrak{a}}$ & $97 \pm 5$ & $106 \pm 7$ & $95 \pm 7$ & $87 \pm 5$ \\
Stressed/Sham & $124 \pm 12^{a}$ & $114 \pm 5$ & $82 \pm 14$ & $137 \pm 1^{b}$ & $130 \pm 5^{c}$ \\
Stressed/ADX & $98 \pm 15$ & $104 \pm 10$ & $59 \pm 6^{b}$ & $75 \pm 20$ & $119 \pm 13$ \\
\hline
\end{tabular}

${ }^{a} p<.05$.

${ }^{b} p<.001$.

${ }^{c} p<.005$.

Table 2. Hippocampal Adenylyl Cyclase Activity and cAMP Concentration

\begin{tabular}{|c|c|c|c|c|c|}
\hline & \multicolumn{3}{|c|}{$\begin{array}{c}\text { Adenylyl Cyclase Activity } \\
\text { (pmol/mg protein) }\end{array}$} & \multicolumn{2}{|c|}{ cAMP Concentration } \\
\hline & NaF & GTP $\gamma \mathrm{S}$ & $n$ & (pmol/mg protein) & $n$ \\
\hline Nonstressed/Sham & $2306 \pm 56$ & $957 \pm 52$ & 6 & $23 \pm 2.4$ & 6 \\
\hline Nonstressed/ADX & $1524 \pm 50^{a}$ & $655 \pm 88^{c}$ & 6 & $20 \pm 2.5$ & 7 \\
\hline Stressed/Sham & $2689 \pm 70^{a}$ & $1054 \pm 33$ & 8 & $31 \pm 1.8^{b}$ & 6 \\
\hline Stessed/ADX & $2640 \pm 109^{b}$ & $1184 \pm 71^{c}$ & 8 & $40 \pm 3.3^{a}$ & 8 \\
\hline
\end{tabular}

to sham condition (Table 2). Restraint stress induced a small but significant increase in both $\mathrm{AC}$ activity and cAMP levels in hippocampus of both sham and adrenalectomized rats (Table 2 ).

\section{DISCUSSION}

Adenylyl cyclase catalyzes the formation of cAMP, an important intracellular second messenger in many eukaryotic cells including neurons of the central nervous system (Krebs and Beavo 1979; Cheung and Storm 1982; Nairn et al. 1985; Levitzki 1987; Greenberg et al. 1993). In the present study, we show that stress can modulate expression of the stimulatory arm of the adenylyl cyclase signal transduction system as well as expression of Goo in the rat hippocampus. Restraint stress was associated with enhanced expression of type I and type II adenylyl cyclase mRNA expression as well as being associated with enhanced expression of Gs $\alpha$, Goa, and G $\beta 36$. Adrenalectomy reduced expression of type II AC mRNA and $G s \alpha$ in both unstressed and stressed rats compared to unstressed and stressed sham rats. The effects of stress on type I AC mRNA expression were not present if rats were adrenalectomized prior to the stress protocol. The effects of stress on type II AC mRNA expression were attenuated if rats were adrenalectomized. In a similar manner, stress did not enhance expression of Gs $\alpha$, Go $\alpha$, and $G \beta 36$ in the adrenalectomized rats. This suggests that glucocorticoids or catecholamines are in part respon- sible for maintaining expression of type I and type II adenylyl cyclase mRNA in the nonstressed state and also responsible for increasing expression of both messages and G-proteins during restraint stress. Expression of $\mathrm{Gi}(1) \alpha$ or $\mathrm{Gi}(2) \alpha$ were not altered by stress.

Both membrane adenylyl cyclase activity and hippocampal CAMP content was increased during restraint stress, even in stressed adrenalectomized rats. The maintenance of cAMP levels in ADX animals during stress may be the result of a significant fall in levels of the inhibitory G-protein, Gi(1) $\alpha$. At this time, we do not know if enhanced expression of AC mRNA was paralleled by an increase in AC membranes protein. Likewise, we do not know if changes in G-protein expression are due to transcriptional or post-transcriptional events.

Because total adrenalectomy was performed (medulla and cortex), the data do not allow us to determine whether adrenal-derived catecholamines or glucocorticoids are responsible for the stress-induced regulation of type I and type II adenylyl cyclase mRNA. However, there are several precedents that have established a role for glucocorticoids in the regulation of AC signal transduction. For example, glucocorticoids increase expression of Gs $\alpha$ in GH3 cells, a rat pituitary cell line (Chang and Bourne 1987). The mechanism by which glucocorticoids increase expression of Gs $\alpha$ is unknown, but the effect is blocked by protein synthesis inhibitors (Chang and Bourne 1987). In rats, 7-day exposure to high levels of glucocorticoids will increase Gs $\alpha$ levels in the frontal cortex (Saito et al. 1989). Adipocyte Gs $\alpha$ levels fall 
following adrenalectomy and normalize again with glucocorticoid replacement (Ros et al. 1989). Moreover, glucocorticoids increase adenylyl cyclase activity in astrocytoma cells and also in vascular smooth muscle (Balmforth et al. 1989; Yasunari et al. 1989). Recently, we showed that stress increases expression of type II adenylyl cyclase mRNA and adenylyl cyclase activity in the rat pituitary (Morrill et al. 1993). Both morphine and cocaine have been shown to modulate the expression of Goa (Nestler et al. 1989; Colin et al. 1991).

There is much evidence for deleterious consequences of glucocorticoids and stress. Excess production of endogenously generated corticosterone results in loss of hippocampal type II glucocorticoid receptors, neuronal injury, and hippocampal-mediated neurological deficits (Landfield et al. 1978; Salpolsky et al. 1984, 1985; Meaney et al. 1991). Animals treated for 3 months with exogenous corticosterone in the upper physiological range (mimicking the elevated basal levels seen in certain rats) show profound hippocampal cell loss ( $\mathrm{CA}_{1}$ and $\mathrm{CA}_{3}$ cell fields) (Salpolsky et al. 1984). In the rat, a reduction in total lifetime glucocorticoid exposure prevents some of the neuronal loss and spacial learning deficits that accompany aging.

In mammalian brain, adenylyl cyclase activity is regulated by neurotransmitter and hormone receptors that are coupled to the enzyme through the G regulatory proteins, Gs and $\mathrm{Gi}$ (Nestler and Greengard 1983). Protein phosphorylation catalyzed by cAMP-dependent protein kinase A regulates several important aspects of neuronal function, including ion channel activity, gene expression, and neurotransmitter synthesis (Nairn et al. 1985; Greenberg et al. 1993). Furthermore, cAMP has been implicated in the regulation of synaptic plasticity and may play an important role in mechanisms underlying learning and memory (Kandel and Schwartz 1982; Dudai and Zvi 1984; Dudai 1988). We speculate that modulation of adenylyl cyclase activity contributes to altered hippocampal function following chronic stress. In man, such observations may explain the pathological consequences of certain disease states associated with excess cortisol production.

We conclude that the stimulatory arm of the adenylyl cyclase signal transduction system as well as Goo are targets of factors released during stress. We speculate that chronic stress has deleterious effects on hippocampal adenylyl cyclase signal transduction, which may impact on health and disease over the lifetime of the individual.

\section{ACKNOWLEDGMENTS}

We thank Drs. Jay Baraban and Rhatan Bhat (Department of Neuroscience, JHU) for helpful discussions and for assistance in the dissection of hippocampal tissue. This work was sup- ported by NIH/NIAAA grant RO1-AA09000 (GSW) and a gift from Alexander and Norma Lattman.

\section{REFERENCES}

Balmforth A, Yasunari K, Vaughen P, Ball S (1989): Glucocorticoids modify differentially dopamine and PGE1 mediated cAMP formation by cultured human astrocytoma clone D384. J Neurochem 52:1613-1618

Chabre O, Conklin BR, Lin HY, Lodish HF, Wilson E, Ives HE (1992): A recobinant calcitonin receptor independently stimulates 3', 5'-cyclic adenosine monophosphate and ca2 +/inositol phosphate signalling pathways. Mol Endocrinology 6:551

Chang F-H, Bourne HR (1987): Dexamethasone increases adenylyl cyclase activity and expression of the $\alpha$-subunit of Gs in GH3 cells. Endocrinology 121:1711-1715

Cheung W, Storm DR (1982): Calmodulin regulation of cAMP metabolism. Handbook Exp Pharmacol 58:301317

Chirgwin JM, Przbyla AE, MacDonald R, Rutter WJ (1979): Isolation of biologically active ribonucleic acid from sources enriched in ribonuclease. Biochemistry 18: 5294-5699

Codina J, Stengel D, Woo SL, Birnbaumer L (1986): Betasubunits of human liver Gs/Gi signal-transducing proteins and those of bovine retinal rod cell transduction are identical. FEBS Lett 207:187-192

Colin SF, Chang HC, Mollner S, Pfeuffer T, Reed RR, Duman RS, Nestler EJ (1991): Chronic lithium regulates the expression of adenylate cyclase and Gi-protein alpha subunit in rat cerebral cortex. Proc Natl Acad Sci USA 88:10634-10637

Dudai Y (1988): Neurogenetic dissection of learning and short-term memory in Drosophila. Annu Rev Neurosci 11:537-563

Dudai Y, Zvi S (1984): Adenylate cyclase in the Drosophila memory mutant rutabaga is defective in its responsiveness to Ca2 +. Neurosci Lett 47:119-124

Feinstein PG, Scharder KA, Bakalyar HA, Tang WJ, Krupinski J, Gilman AG, Reed RR (1991): Molecular cloning and characterization of a $\mathrm{Ca} 2+/$ calmodulin-insensitive adenylyl cyclase from rat brain. Proc Natl Acad Sci USA 88:10173-10177

Gao BN, Gilman AG (1991): Cloning and expression of a widely distributed (type IV) adenylyl cyclase. Proc Natl Acad Sci USA 88:10178-10182

Gilman AG (1990): Regulation of adenylyl cyclase by G proteins. Adv Second Messenger Phosphoprotein Res 24:51-57

Greenberg SM, Castellucci VF, Bayley H, Schwartz JH (1993): A molecular mechanism for long-term sensitization in Aplysia. Nature PY J-1987 329:62-65

Hauger R, Catt KJ, Aguilera G (1990): CRF receptor regulation and sensitization of $A C T H$ responses to acute ether stress during chronic intermittent immobilization stress. Brain Res 532:34-40

Kandel ER, Schwartz JH (1982): Molecular biology of learning: Modulation of transmitter release. Science 218: 433-443 
Krebs EG, Beavo JA (1979): Phosphorylation-dephosphorylation of enzymes. Annu Rev Biochem 48:923-959

Landfield P, Waymire J, Lynch G (1978): Hippocampal aging and adrenocorticoids: A quantitative correlation. Science 202:1098-1101

Levitzki A (1987): Regulation of hormone sensitive adenylate cyclase. Trends Pharmacol Sci 8:299-303

Meaney MJ, Aitken DH, Bhatnager S, Van Berkel C, Sapolsky RM (1988): Postnatal handling attenuates neuroendocrine, anatomical, and cognitive impairments related to the aged hippocampus. Science 238:766-768

Meaney MJ, Mitchell JB, Aitken DH, Bhatnager S, Bodnoff SR, Iny LJ, Sarrieau A (1991): The effects of neonatal handling on the development of the adrenocortical response to stress: Implications for neuropathology and cognitive deficits in later life. Psychoneuroendocrinology 16:85-103

Morrill AC, Wolfgang D, Levin MA, Wand GS (1993): Stress alters adenylyl cyclase activity in the pituitary and frontal cortex of the rat. Life Sci 53:1719-1727

Mumby SM, Kahn RA, Manning DR, Gilman AG (1986): Antisera of designed specificity for subunits of guanine nucleotide-binding regulatory proteins. Proc Natl Acad Sci USA 83:265-269

Munck A, Guyre PM, Holbrook NJ (1984): Physiological functions of glucocorticoids in stress and their relations to pharmacological actions. Endocrine Rev 5:25-44

Nairn AC, Hemmings HC, Greengard P (1985): Protein kinases in the brain. Annu Rev Biochem 54:931-976

Nestler EJ, Greengard P (1983): Protein phosphorylation in the brain. Nature 305:583-588

Nestler EJ, Erdos JJ, Terwilliger R, Duman RS, Tallman JF (1989): Regulation of $G$ proteins by chronic morphine in the rat locus coeruleus. Brain Res 476:230-239

Roff DJ, Applebury ML, Sternweis PC (1985): Relationships within the family of GTP-binding proteins isolated from bovine central nervous system. J Biol Chem 260:1624216249

Ros M, Northup J, Malbon C (1989): Adipocyte G-proteins and adenylyl cylcase. Biochem J 257:737-744

Saito N, Guitart X, Hayward M, Tallman J, Dumon R, Nestler $\mathrm{E}$ (1989): Corticosterone differentially regulates the expression of Gs $\alpha$ and Gi $\alpha$ mRNA and protein in rat cerebral cortex. Proc Natl Acad Sci USA 86:3906-3910

Salomon Y, Londos C, Rodbel M (1974): A highly sensitive adenylyl cyclase assay. Anal Biochem 58:541

Sapolsky RM, Plotsky PM (1990): Hypercortisolism and its possible neural bases. Biol Psychiatry 27:937-952

Sapolsky RM, Krey LC, McEwen BS (1984): Stress downregulates corticosterone receptors in a site-specific manner. Endocrinology 114:287-298

Sapolsky RM, Krey LC, McEwen BS (1985): Prolonged glucocorticoid exposure reduces hippocampal neuron number: Implications for aging. J Neurosci 5:1221-1226

Sternberg EM, Hill JM, Chrousos GP, Kamilaris T, Listwak SJ, Gold PW, Wilder RL (1989): Inflammatory mediatorinduced hypothalamic-pituitary-adrenal axis activation is defective in streptococcal cell wall arthritis-susceptible Lewis rats. Proc Natl Acad Sci USA 86:2374-2378

Tang WJ, Gilman AG (1991): Type-specific regulation of adenylyl cyclase by $\mathrm{G}$ protein beta gamma subunits. Science 254:1500-1503

Tang WJ, Gilman AG (1992): Adenylyl cyclases. Cell 70: 869-872

Tang WJ, Krupinski J, Gilman AG (1991): Expression and characterization of calmodulin-activated (type I) adenylylcyclase. J Biol Chem 266:8595-8603

Taussig R, Iniguez-Lluhl JA, Gilman AG (1993): Inhibition of adenylyl cyclase by Gi alpha. Science 261:218-221

Van Sande J, Raspe E, Perret J, Lejeune C, Maenhaut C, Vassart G, Dumont JE (1990): Thyrotropin activates both the cyclic AMP and PIP2 cascades in CHO cells expressing the human cDNA of TSH receptor. Mol Cell Endocrinol $74: 1-6$

Wand GS, Diehl AM, Levine MA, Wolfgang D, Samy S (1993): Chronic ethanol treatment increases expression of inhibitory $\mathrm{G}$-proteins and reduces adenylyl cyclase activity in the CNS of two lines of ethanol-sensitive mice. J Biol Chem 268:2595

Yasunari K, Kohno M, Balmforth A, Murakawa K, Yokokawa K, Jurihara N, Takeda T (1989): Glucocorticoid and dopamine receptors on vascular smooth muscle cells. Hypertension 13:575-581 